Paediatr Croat. 2014;58:176-83

\title{
Lower leg atrophy in congenital talipes equinovarus
}

\author{
Aliz Bohner-Beke ${ }^{1,2}$, Eleonóra Leidecker², Tamás Koch¹, András Sramó , János Kránicz²
}

Although several authors have addressed calf atrophy, there is no study comparing cases with a sizable control group or describing the development of healthy calf musculature. Keeping in mind the neuromuscular origin of clubfoot, the authors aimed to find out whether the "unaffected" foot is really unaffected in the unilateral clubfoot, and whether its circumference fails to reach the expected measure. The authors examined 60 clubfeet of 40 cases (mean age: 18, range: 3-30 years) and recorded their body weight, height, lower leg length and circumference. To record the same values in healthy controls, the same person examined 1086 feet of 543 subjects aged 4-22 (mean age: 12.5 years). According to the measured values, lower leg length strongly correlates with body height and circumference with body weight. This means the most important developmental trends of these parameters can be demonstrated with polynomial regression models. In unilateral clubfoot, the mean difference in lower leg length and circumference between the affected and unaffected leg was $0.86 \mathrm{~cm}$ and $3.13 \mathrm{~cm}$, respectively. Atrophy of the unaffected leg can be justified at $10 \%$ significance level. In the case of bilateral clubfoot, the difference in length and circumference is justified by numerical results. By recording lower leg length and circumference in controls, the authors pioneered documenting the parameters of healthy calf muscle development. These data can be used to determine the rate of developmental failure in bilateral clubfoot and to reveal the possible involvement of the unaffected leg in unilateral clubfoot.

Keywords: atrophy; clubfoot; child, preschool; child; adolescent

\section{INTRODUCTION}

Successful treatment and management of congenital talipes equinovarus (CTEV) involves several problems. The most common ones are cavus deformity, forefoot inversion, permanent calcaneal equinus, and varus or calcaneal valgus. When the attending physician considers the therapy successful and ends it, calf atrophy still poses considerable challenge. Even if we view calf atrophy as an aesthetic problem only, in most cases it still affects the function of the limb. Clinically, it has been observed that less serious cases are accompanied by less atrophy, while more severe ones are associated with a more substantial degree of atrophy (1). The more severe the deformity, the thinner and more atrophic the calf is $(2,3)$. Both parents and patients themselves often inquire about the cause of this difference in size and its possible solution, and many authors have addressed this issue. A review article by Sobel and Giorgini (1980) summarizes the differences in lower leg circumference (LLC) recorded by various authors in inches (4). Several studies have found calf atrophy to be present in fetuses and aborted newborns with clubfoot. This atrophy primarily affects the triceps surae and tibial posterior muscles. As a result, the belly of these muscles shortens and the tendons lengthen (5-9). Aronson and Puskarich's study was the first to demonstrate that this muscle atrophy of the affected leg cannot be attributed to casting and bracing if therapy duration did not exceed 2 years. Thus, casting would result in reversible atrophy that would not persist, not to mention increase (1) Literature suggests the neuromuscular origin as the possible pathological cause of persistent, progressing and untreatable atrophy (10-14). Still, others think that it is the pro-

\footnotetext{
${ }^{1}$ Eötvös József College, Baja, Hungary

${ }^{2}$ Faculty of Health Sciences, University of Pécs, Pécs, Hungary
}

\section{Correspondence to:}

Aliz Bohner-Beke, Health Sciences PhD School, Faculty of Health Sciences, University of Pécs, H-7621 Pécs, Vörösmarty u.4, Hungary, e-mail: bohner.beke@gmail.com

Primljeno/Received: 3. 3. 2014., Prihvaćeno/Accepted: 17. 7. 2014. 
portion of muscle fiber types (types I and II) that changes, as they found a relative increase in type I fibers on the affected side $(5,10,11,15-22)$. Gray and Katz suggest calf atrophy to be the result of a decrease in the number of muscle fibers (10).

Bechtol and Mossman, then Flinchum have put forward a new hypothesis that in clubfoot muscle growth cannot keep up with bone growth $(5,23)$. Other authors consider CTEV to be a genetic disease, where muscle atrophy is caused by a faulty gene. Dobbs and Gurnett suggest that there might be some connection between the PITX1 mutation and CTEV (25).

Ippolito has raised the question whether leg muscle atrophy in clubfoot is primitive or acquired, i.e. genetically determined or develops as a result of treatment. He found that atrophy was already present in aborted fetuses and untreated newborns suffering from unilateral CTEV, and that it progressed with growth (26).

Several authors have also recorded a decrease in lower leg length (LLL) of the affected limb in unilateral CTEV; however, this issue has never attracted as much interest as the difference in $\operatorname{LLC}(6,7,27-32)$.

As a matter of fact, we have no information about the "normal" parameters of LLC, so that we could compare it with muscle development recorded in clubfoot. In unilateral clubfoot, we always compare the affected limb with the unaffected one, but if we accept the theory of a neuromuscular origin, we cannot know for sure that the "unaffected" leg is really unaffected. In addition, in bilateral CTEV, we have nothing to compare the legs with, unless we collect information on the normal rate of leg muscle development and normal LLC values.

\section{Objectives}

Lower leg atrophy of the affected side is a frequent finding in the physiotherapeutic management of CTEV. In unilateral CTEV, this atrophy is commonly present in the unaffected leg as well, which poses a challenge for the physiotherapist when setting up the treatment plan. Therefore, our aim was to determine the LLC of children with CTEV.

1. Our study aimed to find out whether there is a difference in LLL and LLC between the two legs in unilateral CTEV, and if so, to what degree.

2. In bilateral CTEV, we recorded the same data on both legs and compared them to those of the control group, so that we could determine the normal rate of calf muscle development. Finally, we compared it with calf muscle development experienced in clubfoot.
3. In unilateral CTEV, we used the values of the control group to examine the potential involvement of the unaffected side.

\section{MATERIALS AND METHODS}

\section{CONTROL GROUP}

Altogether we examined 1086 feet of 543 youngsters (308 boys and 235 girls) aged 4-22 (mean age: 12.5 years).

After obtaining the necessary consent from the parents and the principals of the educational institutions, we organized the locomotor examination of the subjects'feet paying special attention to the following aspects:

Body parameters: Body weight was measured using digital scales, with an accuracy of 500 grams. Body height was measured in meters, with a decimal accuracy 2.

When examining $L L L$ and $L L C$, the measurements were always performed by the same person with the same tape measure. The children were sitting on a chair, soles supported by the floor, knees bent at $90^{\circ}$.

LLL measurement:The tape measure touched the lower leg and the distance between the articular groove of the medial tibial plateau and the lower part of the medial malleolus was recorded with an accuracy of $0.5 \mathrm{~cm}$.

LLC measurement: When measuring muscle circumference, identical degree of muscle contraction was used to record the largest calf circumference. The largest circumference was measured by winding the tape around the calf tightly and recorded with an accuracy of $0.5 \mathrm{~cm}$.

\section{CASE GROUP}

We started our investigation at the Department of Traumatology and Hand Surgery, Medical School, University of Pécs in September 2010. During the 2-year study (until September, 2012), we examined 60 clubfeet of 40 patients.

The mean age of the subjects was 18 (range: 3-30) years and gender distribution showed a $62.5 \%$ male predominance. Fifty percent of our cases had unilateral CTEV affecting the right side in a higher proportion of cases (12 patients).

The treatment of cases started in the newborn period (week 1 or 2 at the latest) with the application of serial casting. If conservative therapy did not result in sufficient correction, residual deformity was treated with soft tissue surgery at the age of 8-9 months. Postoperative plaster fixation was applied for 4-6 weeks, followed by active and passive exercise therapy.

As part of the investigation, we took detailed history, performed physical assessment, took $x$-rays if it was considered 
necessary, and got the patient or his/her family to fill in a special questionnaire.

All measurements (body weight/height, LLL and LLC) were performed by the same person and in accordance with the aspects determined when examining the control group.

\section{Statistical analysis}

Data were analyzed with the SPSS Statistics 17.0 software. We used scatter diagrams and basic statistical indices to analyze LLL and LLC values. Data were compared using the Wilcoxon rank sum test, as the distribution of the variables could not be considered normal.

\section{RESULTS}

\section{CONTROL GROUP}

\section{Results of LLL measurements}

Preliminary examinations suggested that there was no difference between men and women or between the left and the right sides if $L L L$ was related to body parameters instead of age. Namely, there is strong correlation between LLL and body height. Data were analyzed by using regression models. The correlation was justified with linear as well as quadratic and cubic regression analyses $(p<0.001)$. We found that the increase in LLL in relation to body height slowed down over time. The best fit was provided by the quadratic model $\left(R^{2}=\right)$. Based on the quadratic model, we could calculate the expected/estimated LLL using body height.

The calculation uses the following formula:

$L L L=-22.502+52.018 *$ body height $-9.190 *$ body height ${ }^{2}$

\section{Results of LLC measurements}

Just as LLL strongly correlates with body height, the same relationship can be detected between LLC and body weight. We also ruled out the possibility that gender or laterality had an influence on the results.

As a result of the slight inclination in the middle of the cloud, we performed linear as well as quadratic and cubic regression analyses. The regression analysis of all 3 models yielded acceptable results $(p<0.001)$. The correlation was justified by all three regression models. The best fit was provided by the cubic model, so we used the following formula to calculate the expected or estimated value:

\section{LLC $=12.868+0.637^{*}$ body weight $-0.005^{*}$ body weight ${ }^{2}+$ $+0.00002224^{*}$ body weight ${ }^{3}$}

Based on the polynomial regression analyses, you have to substitute body height if you want to determine LLL and body weight if you want to know LLC.

\section{CASE GROUP}

\section{Unilateral CTEV}

\section{Differences in LLL}

When illustrating the length of both lower legs in unilateral CTEV, it became apparent that the unaffected leg was longer than the affected one (Figure 1). The difference between the affected and the unaffected side was statistically significant $(p=0.01)$.

\section{Differences in LLC}

When comparing the circumference of the lower legs in unilateral CTEV, we found that the rate of difference between the two legs was much higher than in case of LLL (Figure 2); the difference was statistically significant $(p<0.001)$.

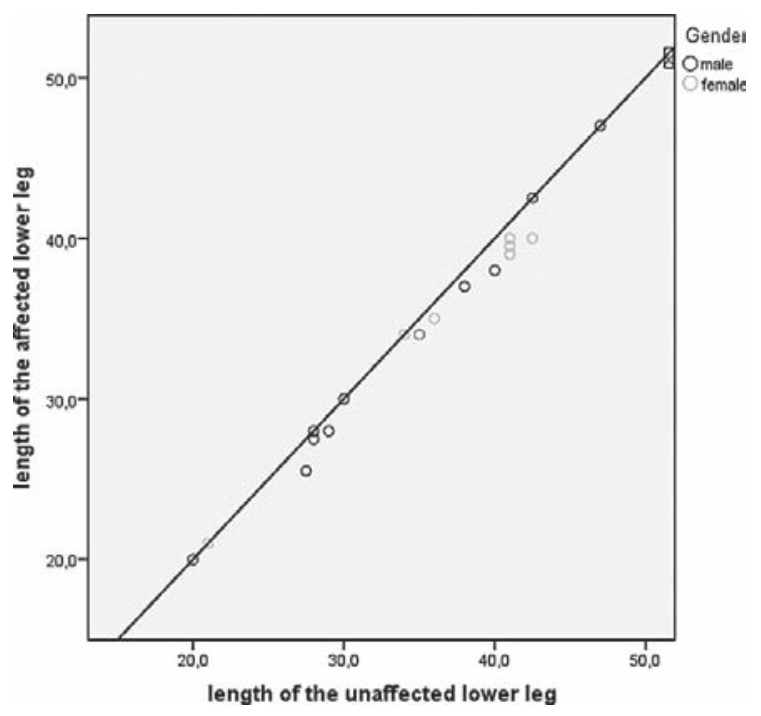

FIGURE 1. Length of the affected and unaffected lower leg $(\mathrm{cm})$

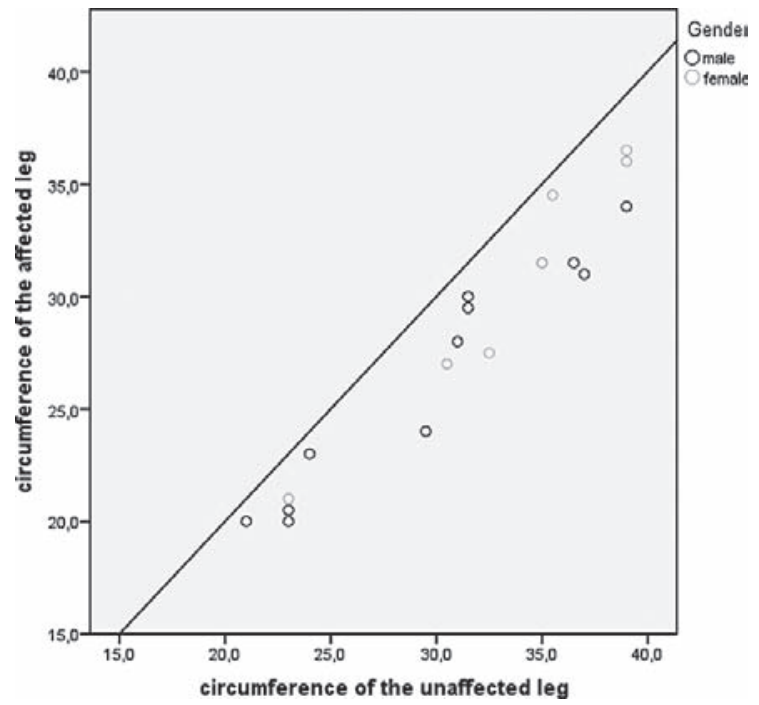

FIGURE 2. Circumference of the affected and unaffected lower leg (cm) 


\section{Difference between the affected side and estimated values}

In unilateral CTEV, when comparing the affected side to the estimated values based on the examination of the control group, the LLL values approximated, while LLC values failed to reach those of the control group (Figure 3). The difference between LLL values was not significant; however, the difference between $\mathrm{LLC}$ values was statistically significant $(p<0.001)$. The diagrams reveal that the circumference shows greater spreading and its values lag further behind the expected ones.

\section{Difference between the unaffected size and estimated values}

When we compared the unaffected side to the normal growth trends, LLC was still somewhat below the expected values, although that rate of difference was not as substantial as in the case of the affected leg (Figure 4).

The difference between LLL values was not statistically significant; however, in the case of LLC, the difference was significant at the $10 \%$ level of significance $(p=0.073)$, which is acceptable considering age distribution and the statistical model applied.
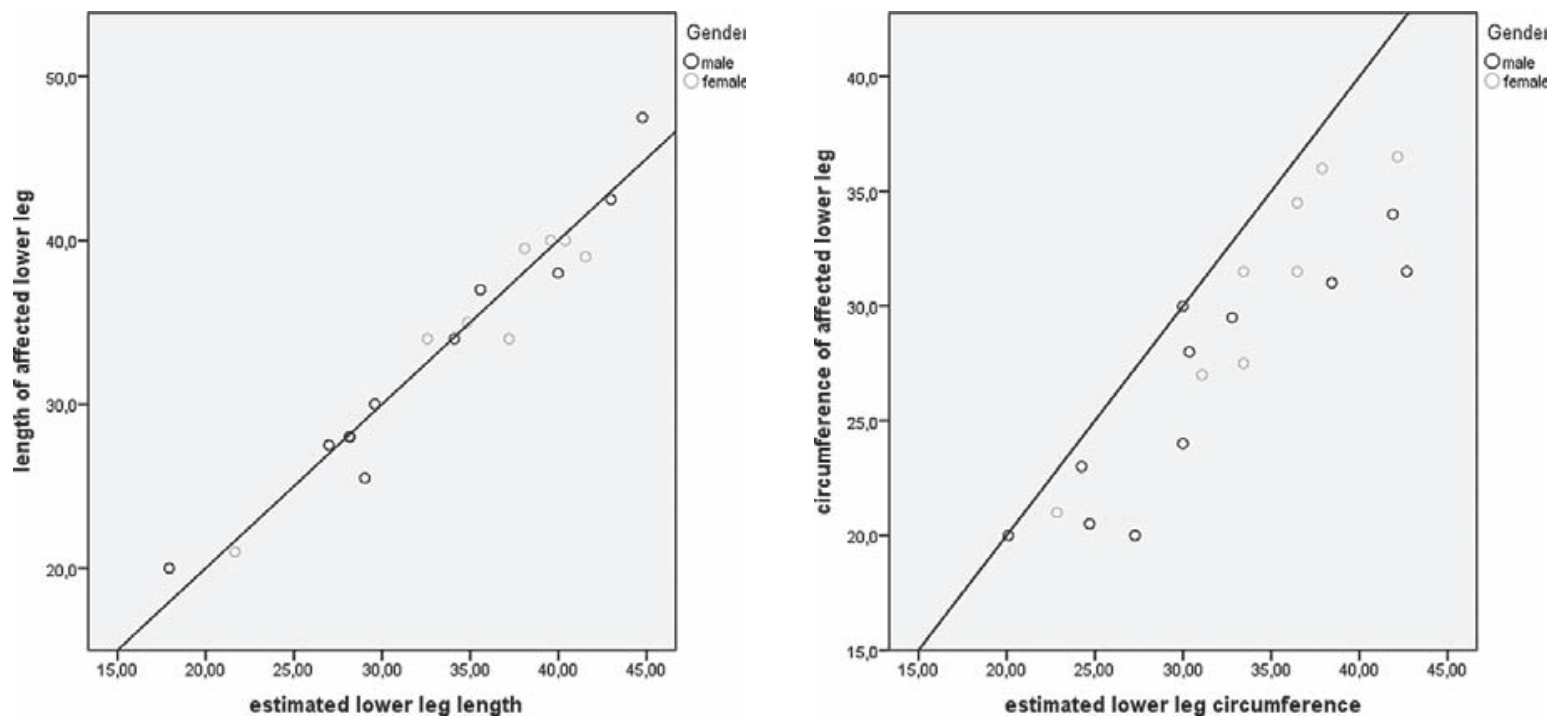

FIGURE 3. Affected and estimated lower leg length (left), affected and estimated lower leg circumference (cm)
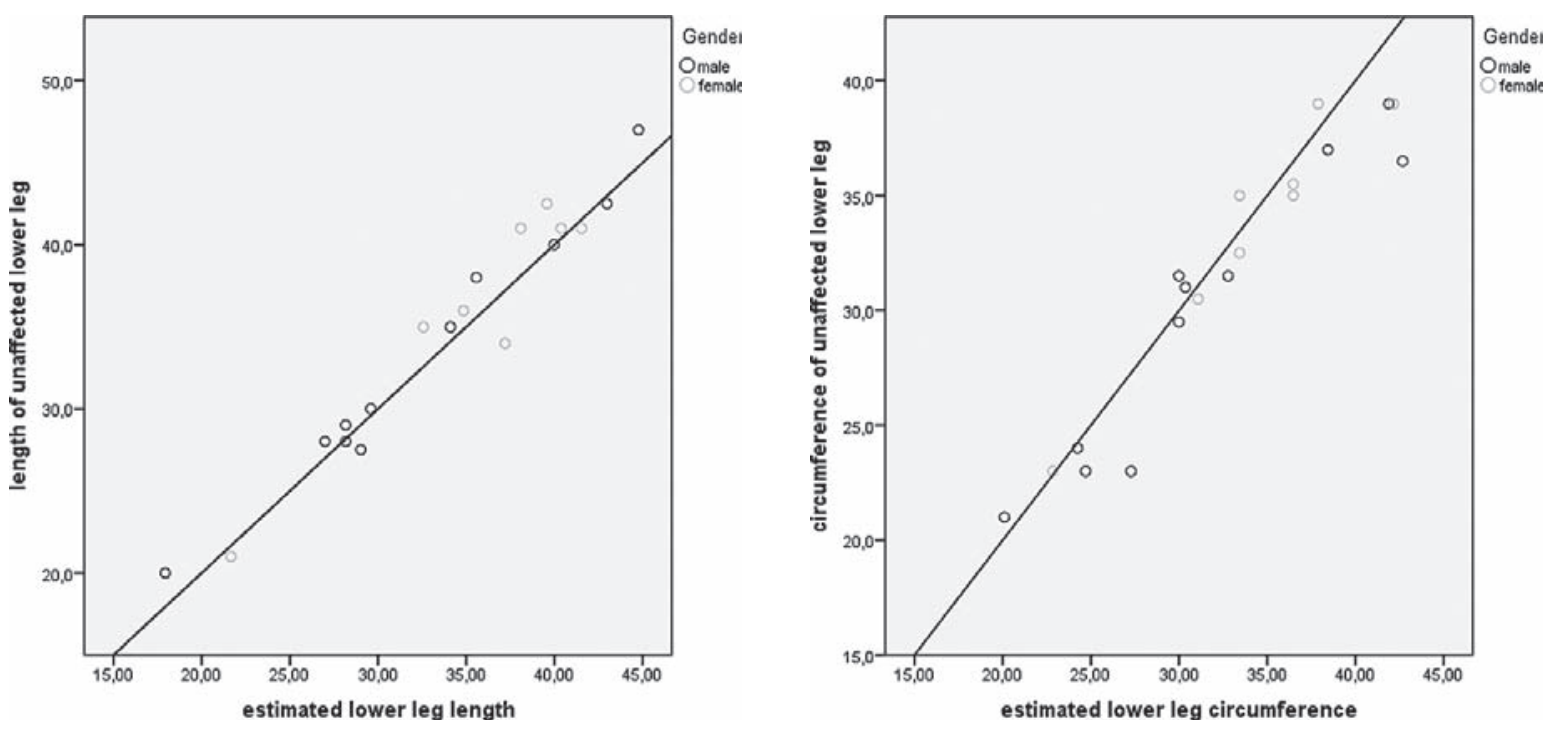

FIGURE 4. Unaffected and estimated lower leg length (left), unaffected and estimated lower leg circumference (cm) 

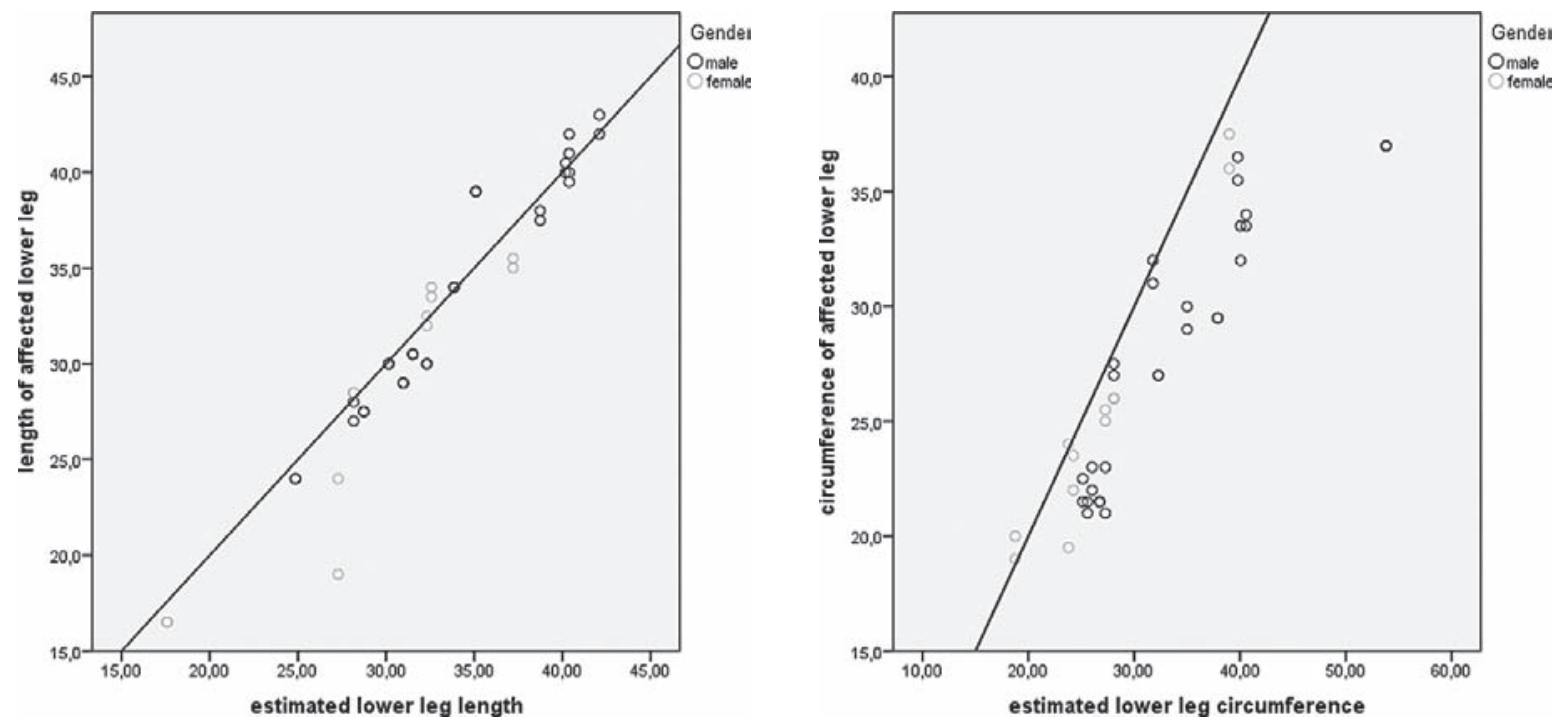

FIGURE 5. Affected and estimated leg length (left), affected and estimated leg circumference in bilateral clufoot (cm)

\section{Bilateral CTEV}

A failure to reach the estimated values was also apparent in bilateral CTEV, and the difference was more marked when comparing LLC (Figure 5). The difference between the expected and the actual values was significant both in the case of LLL ( $p=0.0019)$ and LLC $(p<0.001)$.

\section{DISCUSSION}

\section{Control group}

During the objective investigation, we considered all the measured parameters to determine two variables that correlate most strongly with LLL and LLC. These variables were body height and body weight, respectively. Based on this, the most important developmental tendencies of these parameters can be illustrated by using polynomial regression models.

As a function of body height and weight, we can anticipate normal LLL and expected LLC, with regression used to obtain body proportions.

\section{Case group}

LLL

In unilateral CTEV, the mean difference between the affected and the unaffected legs was $0.86 \mathrm{~cm}$. If we compare our results with those reported from international studies, three factors have to be considered: how they measured the difference, what age their cases were and how the patients were treated.
Noonan et al. report on three cases; the mean difference between the two legs was $2.1 \mathrm{~cm}$ (range: 2.0-2.3). Their patients were treated with extensive soft tissue surgery and the measurements were performed on lateral $x$-ray images (30)

Merrill et al. examined 11 patients, mean age 16.5 (range: 6$60)$ years. The patients had been treated with the Ponseti method and the measurements were performed with the help of magnetic resonance imaging (MRI). The difference between the two tibiae was measured in eight patients, while the difference between the two fibulae was measured in five cases. They found that the tibia of the affected side was shorter in all cases, the mean difference being $0.68 \pm 0.26 \mathrm{~cm}$ (range: 0.46-0.94). The affected fibulae were also shorter in all patients; mean difference: $0.87 \pm 0.45 \mathrm{~cm}$ (range: 0.54-1.63) (32).

\section{LLC}

In unilateral CTEV, the mean difference between the circumference of the lower legs was three $\mathrm{cm}$ in our study and it corresponds with some international results, although the method of measurement may be different.

Sobel and Giorgini summarized and tabularized the results of 11 publications on LLC difference published during the 1980-2001 period. The mean difference of the recorded values was $1.52 \mathrm{~cm}$ (range: 0.76-3.56) (4).

The aim of Gamble was to answer parental questions. He wanted to find out more about the development of this difference in unilateral CTEV and also to know if the degree of the difference was affected by the treatment of choice (po- 
steromedial release, Ponseti technique). He used a tape measure for his measurements and found that the mean difference in size between the two calves was 9.83\% ( $N=93)$, which did not seem to be influenced by the treatment method (33). If our circumference results are converted into percentage, it will result in the mean difference of $11.6 \%$, which is close to Gamble's 10\% in patients that underwent posteromedial release.

Aronson and Puskarich examined 29 cases with unilateral CTV and 23 controls. Their cases were also treated with posteromedial release and the difference between the volumes of the two lower legs was also 10\% (1).

Chesney compared objective and subjective parameters when characterizing treatment results. The most important difference between the two studies is the circumference, which is meant to be the "normal" one. It would be difficult to study developmental failure in bilateral CTEV as there is nothing to compare the measured values with, and there are no expected "normal" values in the literature either. Chesney's study used the circumference of the unaffected leg as a reference value; however, in our opinion, it cannot be considered normal either. In his opinion, the most useful anthropometric measurements when assessing clubfoot are $L L L$ and LLC. This confirms the clinical observation that in less severe cases, the difference between the circumference of the lower legs is smaller, while it is more pronounced in more severe cases. The function of the leg also corresponds with the rate of this difference (34).

If we divide those with unilateral CTEV into 3 groups (according to age) with approximately the same number of patients in each, we can determine the mean difference in LLC. As a result, we can see that the mean difference in circumference is $1.5 \mathrm{~cm}$ in group 1 ( $n=6$, age: $2-8$ years), 3.69 $\mathrm{cm}$ in group 2 ( $\mathrm{n}=8$, age: $9-13$ years) and $4.11 \mathrm{~cm}$ in group 3 ( $n=7$, age: $14-37$ years).

The relationship between age and lower leg atrophy is similar to that found by Ippolito, i.e. atrophy progresses with age (26).

It is also apparent that the circumference of the "unaffected" leg fails to reach the estimated value, which supports the neuromuscular origin.

In bilateral CTEV, LLC also fails to reach the estimated value, and the rate of this failure can be determined precisely by using the formula of the regression equations.

In our opinion, the difference between our study and the previous ones in this field lies in the fact that we compared LLC in unilateral CTEV not only to the 'unaffected' leg but also to the values obtained from a sizeable control group. In addition, we have provided a new basis for measurements and reference values for the assessment of bilateral CTEV.

\section{CONCLUSIONS}

1. We found that the circumference of the affected lower leg in unilateral CTEV fails to reach that of the unaffected one.

2. The rate of atrophy in bilateral CTEV can be determined and our calculations revealed correlations that have been unknown before, namely, the close relationship between LLL/LLC and other body parameters.

3. The involvement of the unaffected side can be justified as well. In order to get a clearer picture, we will have to include more patients or limit the physiological variation.

The most appropriate imaging techniques for measuring LLL are MRI and especially Extended Orthopedic System 2D/3D ultra-low dose orthopedic machines.

Tape measurements proved to be credible in the measurement of LLC when assessing atrophy. In our case, the size of the control group justified its use.

The method of measurement used in our study is simple, available to everyone, can be included in physical examination, and the rate of developmental failure is easy to calculate based on the formulas that have resulted from the study.

\section{NOVČANA POTPORA/FUNDING \\ Nema/None}

\section{ETIČKO ODOBRENJE/ETHICAL APPROVAL}

Nije potrebno/None

\section{DOPRINOSI AUTORA/DECLARATION OF AUTHORSHIP}

Svi autori jednako su doprinijeli izradi rada/All authors have equally contributed to a manuscript writing.

\section{SUKOB INTERESA/CONFLICT OF INTEREST}

Autori su popunili the Unified Competing Interest form na www.icmje.org/ coi_disclosure.pdf (dostupno na zahtjev) obrazac i izjavljuju: nemaju potporu niti jedne organizacije za objavljeni rad; nemaju financijsku potporu niti jedne organizacije koja bi mogla imati interes za objavu ovog rada u posljednje 3 godine; nemaju drugih veza ili aktivnosti koje bi mogle utjecati na objavljeni rad./All authors have completed the Unified Competing Interest form at www.icmje.org/coi_disclosure.pdf (available on request from the corresponding author) and declare: no support from any organization for the submitted work; no financial relationships with any organizations that might have an interest in the submitted work in the previous 3 years; no other relationships or activities that could appear to have influenced the submitted work.

\section{REFERENCES}

1. Aronson J, Puskarich CL. Deformity and disability from treated clubfoot. J Pediatr Orthop. 1990;10:109-19. http://dx.doi.org/10.1097/01241398-199001000-00022

2. Adams W. Clubfoot: its causes, pathology and treatment. $2^{\text {nd }}$ ed. London Churchill; 1866.

3. Kaplan EB. Comparative anatomy of the talus in relation to idiopathic clubfoot. Clin Orthop. 1972;85:32-7.

http://dx.doi.org/10.1097/00003086-197206000-00008 
4. Sobel E, Giorgini JR. Identification and management of clubfoot. Podiatry Management. 2002;131-54.

5. Bechtol CO, Mossman HW. Clubfoot; : an embryological study of associated muscle abnormalities. J Bone Joint Surg Am. 1950;32:827-38.

6. Laaveg SJ, Ponseti IV. Long-term results of treatment of congenital club foot. J Bone Joint Surg Am. 1980;62:23-31.

7. Hutchins PM, Foster BK, Paterson DC, Cole EA. Long-term results of early surgical release in club feet. J Bone Joint Surg Br.1985;67:791-9.

8. Kránicz J, Than P, Kustos T. Long-term results of the operative treatment of clubfoot: a representative study. Orthopedics.1998;21:669-74.

9. Ippolito E, Farsetti P, Caterini R, Tudisco C. Long-term comparative results in patients with congenital clubfoot treated with two different protocols. J Bone Joint Surg Am. 2003;85:1286-94.

10. Gray D, Katz J. A histochemical study of muscle in clubfoot. J Bone Joint Surg. 1981;63-B:417-23.

11. Handelsman J, Badalamente M. Neuromuscular studies in clubfoot. J Pediatr Orthop.1981;1:23-32. http://dx.doi.org/10.1097/01241398-198101010-00004

12. Isaacs $\mathrm{H}$, Handelsman J, Badenhorst $\mathrm{M}$, Pickering $\mathrm{A}$. The muscles in clubfoot - a histological, histochemical, and electron microscopy study. J Bone Joint Surg. 1977;59-B:465-72.

13. Kojima A, Nakahara $\mathrm{H}$, Shimizu N, et al. Histochemical studies in congenital clubfeet. In: Simons G W, ed. The Clubfoot. New York: Springer-Verlag; 1994:16-20. http://dx.doi.org/10.1007/978-1-4613-9269-9_4

14. Shimizu N, Hamada S, Mitta M, Hiroshima, Ono K. Considerations of Congenital congenital Clubfoot clubfoot Deformitydeformity. In: Simons GW, ed. The Clubfoot. New York: Springer-Verlag; 1994:31-8.

15. Kránicz J, Trombitás K, Szepesi J. Dongalábas betegek izmain végzett ultrastrukturális vizsgálatok. Magy Traumatol Orthop Helyreállító Seb. 1980;23:89-97.

16. Kranicz J, Trombitas K, Szabo Gy. Results of ultrastructural analysis of the calf muscles in clubfoot. Orthopedics. 1991;14:73-5.

17. Gosztonyi G, Dorfmüller-Küchlin S, Sparmann M, Eisenschenk A Morphometric study of muscle in congenital idiopathic clubfoot. Pathol Res Pract. 1989;185:790-4. http://dx.doi.org/10.1016/S0344-0338(89)80241-9

18. Handelsman JE, Glasser R. Musclepathology in clubfoot and lower motor neuron lesions. In: Simons GW, ed. The Clubfoot. New York: Springer-Verlag; 1994:21-31. http://dx.doi.org/10.1007/978-1-4613-9269-9_5

19. Herceg MB, Weiner DS, Agamanolis DP, Hawk D. Histologic and histochemical analysis of muscle specimens in idiopathictali pes equinovarus. J Pediatr Orthop. 2006;26:91-3. http://dx.doi.org/10.1097/01.bpo.0000188994.90931.e8
20. Loren GJ, Karpinski NC, Mubarak SJ. Clinical implications of clubfoot histopathology. J Pediatr Orthop.1998;8:765-9. http://dx.doi.org/10.1097/01241398-199811000-00013

21. Maffulli N, Capasso G, Testa V, Borrelli L. Histochemistry of the triceps surae muscle in idiopathic congenital clubfoot. Foot Ankle. 1992;13:80-4. http://dx.doi.org/10.1177/107110079201300205

22. SircaA, Erzen I, Pecak F. Histochemistry of abductor hallucis muscle in children with idiopathic clubfoot and in controls. J Pediatr Orthop. 1990;10:477-82. http://dx.doi.org/10.1097/01241398-199010040-00009

23. Flinchum D. Pathological anatomy in talipes equinovarus. J Bone Joint Surg Am. 1953;35:111-4.

24. Ester AR, Tyerman G, Wise CA, Blanton SH, Hecht JT. Apoptotic gene analysis in idiopathic talipes equinovarus (clubfoot). Clin Orthop Relat Res. 2007;462:32-7 http://dx.doi.org/10.1097/BLO.0b013e318073c2d9

25. Dobbs MB, Gurnett CA. Genetics of clubfoot. J Pediatr Orthop B. 2012;21:7-9. http://dx.doi.org/10.1097/BPB.0b013e328349927c

26. Ippolito $E$, Maio De F, Mancini F, Bellini D, Orefice A. Leg muscle atrophy in idiopathic congenital clubfoot: is it primitive or acquired? J Child Orthop. 2009; 3:171-8. http://dx.doi.org/10.1007/s11832-009-0179-4

27. Atar $D$, Lehman WB, Grant AD, Strongwater AM. Revision clubfoot surgery. In: Jahss M, ed. Disorders of the foot and Ankle, Part III. $2^{\text {nd }}$ ed. Philadelphia: W.B. Saunders: 1991;830-40.

28. Ghali NN, Smith RB, Clayden AD, Silk FF. The results of plantar reduction of congenital talipes equinovarus. J Bone Joint Surg. 1983;65B:1-7.

29. Little DG, Aiena MD. Limb length discrepancy in congenital talipes equinovarus. The Australian and New Zealand. J Surg. 1995;65:409-11. http://dx.doi.org/10.1111/j.1445-2197.1995.tb01770.x

30. Noonan KJ, Meyers AM, Kayes K. Leg length discrepancy in congenital clubfoot following surgical treatment. lowa Orthop J. 2004;24:60-4.

31. Shimode K, Miyagi N, Majima T, Yasuda K, Minami A. Limb length and girth discrepancy of unilateral congenital clubfoot. J Ped Orthop. 2005;14:280-4.

32. Merrill LJ, Gurnett CA, Siegel M, Sonavane S, Dobbs MB. Vascular abnormalities correlate with decreased soft tissue volumes in idiopathic clubfoot. Clin Orthop Relat Res. 2011;469:1442-9. http://dx.doi.org/10.1007/s11999-010-1657-1

33. Gamble J, Batista E, Rinsky L. Howsmall I. The leg and foot in unilateral clubfoot. Brit Ed Soc Bone Joint Surg. 2012;94 (Suppl 21):34.

34. Chesney D, Baker S, Maffuli N. Subjective and objective outcome in congenital clubfoot; a comparative study of 204 children. BMC Musculoscelet Disord. 2007;8:53. http://dx.doi.org/10.1186/1471-2474-8-53 


\title{
SAZ̈ETAK
}

\section{Atrofija potkoljenice kod prirođene deformacije talipes equinovarus}

\author{
Aliz Bohner-Beke, Eleonóra Leidecker, Tamás Koch, András Sramó, János Kránicz
}

lako su se mnogi autori bavili atrofijom lista noge, ni u jednoj studiji nisu uspoređeni slučajevi s podjednakom kontrolnom skupinom niti je opisan razvoj zdravog mišićja lista noge. Vodeći računa o neuromuskularnom podrijetlu talipesa, cilj studije bio je nastojati utvrditi da li "nezahvaćeno" stopalo doista nije zahvaćeno kod jednostranog talipesa te da li njegov opseg dostiže očekivane mjere. Autori su ispitali 60 stopala zahvaćenih talipesom u 40 slučajeva (srednja dob 18, raspon 3-30 godina) te zabilježili njihovu tjelesnu masu, visinu, duljinu i opseg potkoljenice. Isti ispitivač zabilježio je iste parametre kod 1086 stopala u 543 osobe u dobi od 4-22 godine (srednja dob 12,5 godina) kako bi se utvrdile njihove vrijednosti kod zdravih kontrolnih osoba. Prema izmjerenim vrijednostima, duljina potkoljenice snažno korelira s tjelesnom visinom, a njezin opseg s tjelesnom masom. To znači da se najvažniji razvojni trendovi ovih parametara mogu opisati pomoću modela polinomijalne regresije. Kod jednostranog talipesa je srednja razlika u duljini i opsegu potkoljenice između zahvaćene i nezahvaćene noge bila 0,86 cm odnosno 3,13 cm. Atrofija nezahvaćene noge može se dokazati na razini značajnosti od 10\%. U slučaju obostranog talipesa razlika u duljini i opsegu dokazuje se prema brojčanim rezultatima. Mjerenjem duljine i opsega potkoljenice u kontrolnih osoba autori su prvi put dokumentirali parametre razvoja zdravog mišićja lista noge. Ovi podaci mogu se rabiti za utvrđivanje razvojnog poremećaja kod obostranog talipesa, kao i za otkrivanje moguće zahvaćenosti nezahvaćene noge kod jednostranog talipesa.

Ključne riječi: atrofija; talipes; dijete, predškolsko; dijete; adolescent 